Article

\title{
Comparative Analysis of Urban Heat Island Intensities in Chinese, Russian, and DPRK Regions across the Transnational Urban Agglomeration of the Tumen River in Northeast Asia
}

\author{
Bing $\mathrm{Li}^{1}$, Zhifeng Liu ${ }^{2,3}$, Ying Nan ${ }^{1, *}$, Shengnan $\mathrm{Li}^{1}$ and Yanmin Yang ${ }^{1}$ \\ 1 Department of Geography, Yanbian University, Yanji 133000, China; 2016010437@ybu.edu.cn (B.L.); \\ 2016010424@ybu.edu.cn (S.L.); 2017010453@ybu.edu.cn (Y.Y.) \\ 2 Center for Human-Environment System Sustainability (CHESS), State Key Laboratory of Earth Surface \\ Processes and Resource Ecology (ESPRE), Beijing Normal University, Beijing 100875, China; \\ zhifeng.liu@bnu.edu.cn \\ 3 Faculty of Geographical Science, Beijing Normal University, Beijing 100875, China \\ * Correspondence: nanying@ybu.edu.cn; Tel.: +86-0433-273-3679
}

Received: 6 June 2018; Accepted: 18 July 2018; Published: 27 July 2018

\begin{abstract}
Quantification of the spatial pattern of urban heat island intensities across the transnational urban agglomeration of the Tumen River is important for the promotion of sustainable regional development. This study employed Landsat images and MODIS LST data obtained in 2016 to determine the intensity of urban heat islands in this region, enabling direct comparison of data from the sub-regions of China, Democratic People's Republic of Korea (DPRK), and Russia. The average urban heat island intensity for the region was found to be $1.0^{\circ} \mathrm{C}$, with the highest intensity of $3.0^{\circ} \mathrm{C}$ occurring during the summer time. The intensity of urban heat islands on the Chinese side was higher than on the other two sides, with city size, socio-economic development levels and vegetation coverage significantly affect their intensity. Urban heat island effects in Chinese cities in the region contribute increases in maximum summer temperatures and the number of high-temperature days that pose a threat to the health of their residents. The factors that influence urban heat island intensities in these cities and the impacts of urban heat island effects on the quality of life and health of residents are discussed. Therefore, it is desirable to reduce the impact of urban heat island effects on cities in the region by increasing the area of green spaces they contain, as well as controlling their size and population.
\end{abstract}

Keywords: transnational urban agglomeration of Tumen River; China; Democratic People's Republic of Korea; Russia; urban heat island intensity; land surface temperature

\section{Introduction}

Urban temperatures are significantly higher than those in the rural areas [1-3], with Urban Heat Island Intensity (UHII) values [4] used to quantify these temperature differences [1]. These urban heat island effects can directly (or indirectly) affect local climates [5], energy use [6,7], air quality [8,9], the physical and chemical properties of soil [10], land surface phenology [11,12], biodiversity [13] and natural/socio-economic factors that affect human health and comfort levels $[6,14-16]$. Therefore, it is necessary to quantify the pattern of UHII so that their effect on urban environments can be alleviated to increase the sustainability of cities and improve living conditions of their residents.

The transnational urban agglomeration of the Tumen River (TUATR) in northeastern Asia is located across the region of China, Democratic People's Republic of Korea (DPRK) and Russia, with this 
geographical area including the major port cities of Vladivostok, Luojin, and Chongin $[9,17]$ (Figure 1). This region represents an important part of the "Chinese-Russian-DPRK-Mongolia" international channel as a key component of the Chinese "The Belt and Road" strategy [17], which has also been identified as a key region for the development of Russia's Far East region and Luoxian Economic Zone in DPRK. Therefore, the sustainable development of regional cities in this area is of great importance to three countries [18-20]. The rapid urbanization of this region has resulted in an increase in the UHII in this area [21], with global warming predicted to increase the temperature of this region further [22,23]. Therefore, quantifying the spatial pattern of UHII across the TUATR is important to promote the sustainable development of regional cities in this area.

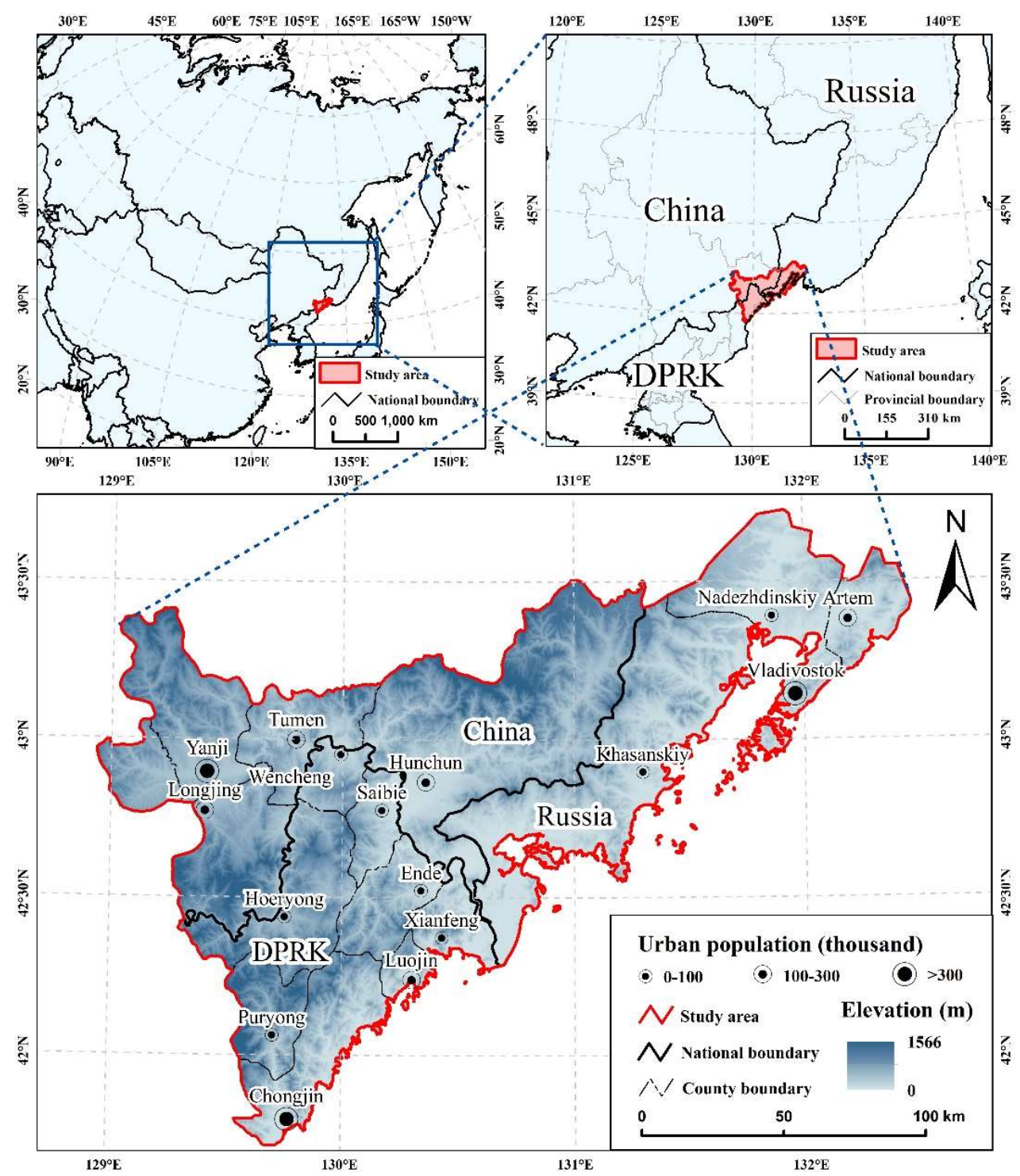

Figure 1. The transnational urban agglomeration of the Tumen River (TUATR).

Recent reports have quantified the UHII present in the TUATR. Gao et al. [21] analyzed the spatial pattern of UHII in Yanji City on the Chinese side of the TUATR in 2004, however, a study of UHII in the entire region is currently lacking. The main reason for this lack of information is the fact that UHII data has previously been sourced from meteorological stations, with significant differences in the number, spatial distribution, and availability of meteorological stations across the region of China, DPRK and Russia. This lack of coverage makes it difficult to effectively quantify UHII across the whole TUATR in a timely and effective manner. 
Land Surface Temperature (LST) data obtained from Moderate-Resolution Imaging Spectroradiometer (MODIS) sensors provide an alternative data source for quantifying the UHII [24-27]. LST provides an indicator of the thermal conditions at the ground-air interface that is closely related to air temperatures, thus providing an effective way of quantifying the UHII [28]. Calibrated MODIS LST data $[29,30]$ is sufficiently accurate to provide spatial resolution for data of around $1 \mathrm{~km}$, which enables analysis of UHII to be carried out in large-scale cities [31]. Moreover, MODIS LST data can be used in a time-resolved mode to effectively reflect dynamic changes in UHII [32]. This has resulted in MODIS LST data being widely used for the study of UHII Clinton and Gong [7], with Miles et al. [33] using this approach to analyze the UHII in 28 cities in Siberia during summer and winter.

The purpose of this study was to quantify the spatial pattern of UHII across the TUATR throughout 2016. Landsat remote sensing images have been used to extract urban land information for this study area, with MODIS LST data used to analyze UHII across the entire region which enabled intensities in the region of China, DPRK and Russia to be compared. The factors that influence urban heat island effects and their potential impact on the sustainability of cities and the health of their residents are also discussed.

\section{Study Area and Data}

\subsection{Overview of the Study Area}

The TUATR is located between longitudes $128^{\circ} 00^{\prime}-133^{\circ} 00^{\prime}$ and $41^{\circ} 00^{\prime}-44^{\circ} 00^{\prime}$ latitudes, comprising a total area of around $24,000 \mathrm{~km}^{2}$ (Figure 1). This region experiences a mid-temperate monsoon climate with northwestern winds prevailing in winter and southeast winds predominating in summer [34], with an average annual precipitation of between $400-650 \mathrm{~mm}$ and an average annual temperature between $2-6{ }^{\circ} \mathrm{C}$ [9]. Its terrain gradually increases from the southeast coast to the northwest interior, with the lowest point being less than $20 \mathrm{~m}$ and the highest point nearly $1600 \mathrm{~m}$ above sea level. Ocean influences result in coastal areas having a moist, foggy climate expected for a typical coastal region.

The TUATR is located at the borders of China, DPRK and Russia [9], with the Chinese side containing Yanji City, Longjing City, Tumen City and Hunchun City in the Yanbian Korean Autonomous Prefecture of Jilin Province. The Chinese side covers an area of approximately 10,100 square kilometers. The North Hamgyong Province on the side in DPRK covers an area of approximately 6800 square kilometers, which includes the cities of Hoeryong County, Puryong County, Wencheng County, Saibie County, Ende County, Chongjin City, Luojin City and Xianfeng County. The Russian side of the river covers an area of approximately 7100 square kilometers, including the major cities Vladivostok, Artem, Hassan, and Nakhilkinsk. The total population of the region in 2016 was 9.03 million, with an urban population of 2.31 million corresponding to an urbanization rate of $25.57 \%$, with three cities containing more than 300,000 people-Yanji City on the Chinese side, Chongjin City on the side in DPRK and Vladivostok on the Russian side.

\subsection{Data}

The MODIS LST 8-day composites for 2016 were used to quantify the UHII sourced from MOD11A2 V006 and MYD11A2 V006 datasets released by the National Aeronautics and Space Administration (NASA)/Goddard Space Flight Center (GSFC) (http:/ / ladsweb.nascom.nasa.gov / data). The spatial resolution of the data was $1 \mathrm{~km}$, with LST information measured at 10:30 and 13:30 during the day and 22:30 and 01:30 at night. The method of Wan et al. [35] was used to compile monthly averages of MODIS LST data for each time period after removing the pixels with abnormal values due to cloud, fires, smokestacks, and etc. Landsat 8 Operational Land Imager (OLI) imagery from the United States Geological Survey (http://glovis.usgs.gov) was used to extract urban land information. The spatial resolution of this data was $30 \mathrm{~m}$, comprising a total of four sets of remote sensing images (Table A1). 
MODIS Normalized Difference Vegetation Index (NDVI) data was used to analyze the factors influencing UHII using information sourced from the MOD13Q1 dataset obtained from NASA (http://ladsweb.nascom.nasa.gov/data). Information from National Oceanic and Atmospheric Administration (NOAA)'s Visible Infrared Imaging Radiometer on the National Polar-orbiting Operational Environmental Satellite System (NPOESS) of the Preparatory Program (NPP) was used to provide nighttime lighting data that was obtained through the NOAA/National Geophysical Data Center (NGDC) (http:/ /ngdc.noaa.gov/ eog). White-sky albedo (WSA) data was sourced from the NASA MCD43A3 dataset (http:/ /ladsweb.nascom.nasa.gov/data). Digital Elevation Model (DEM) data was sourced from the Geospatial Data Cloud Platform (http:/ /www.gscloud.cn) of the Computer Network Information Center of the Chinese Academy of Sciences. The spatial resolution of the data was $90 \mathrm{~m}$, and this data was generated from NASA's Shuttle Radar Topography Mission (SRTM) in 2000. Population data was sourced from the Netherlands Environment Assessment Agencies (NEAA)'s Historical Database of the Global Environment (HYDE) (http://www.mnp.nl/hyde). Data on the population of children and elderly people from the China and DPRK were sourced from the AsiaPop project (http:/ / www.worldpop.org.uk/data/summary/?doi=10.5258/SOTON/WP00012). The spatial resolution of the data was $1 \mathrm{~km}$, and this data is compiled from demographic age/sex structure proportional data, sourced on a country-by-country basis. Temperature observation data for the Chinese side were extracted from historical weather data (http://tianqi.2345.com/).

The administrative boundary data for the Chinese side were taken from 1:4 million national and provincial vector administrative boundary data (http://ngcc.sbsm.gov.cn) issued by the National Basic Geographic Information Center of China. The administrative boundary data for the sides in DPRK and Russia were obtained from the Global Administrative Region Boundary Data Set (http://www.gadm.org/).

\section{Methodologies}

The method of Tao et al. [36] was used to extract regional urban land from Landsat images taken in 2016 (please refer to Text A1 in the Appendix A for details). Here, the urban land denotes the urban built-up area, i.e., the portion that is dominated (more than $50 \%$ in cover) by non-vegetated, human-constructed elements, such as roads, buildings, runways, and industrial facilities [37]. Analysis of the accuracy of the urban land used in this study were carried out using high-resolution remote sensing data from Google Earth, which showed that the overall accuracy of the data was $88.25 \%$ with a Kappa coefficient of 0.87 . This indicates that the data used in this study accurately reflected the spatial pattern of regional urban land use.

The method of [7], was used to quantify the UHII at different time periods based on differences between LST levels of urban land and a $10 \mathrm{~km}$ buffer zone around the urban land (Figure A1). The UHII was calculated using Equation (1):

$$
U H I I_{i, m, t}=\overline{L S T}_{i, m, t}^{U}-\overline{L S T}_{i, m, t}^{R}
$$

where, $U H I I_{i, m, t}$ represents the UHII of the $i$-th city in the m-th month of the $t$-th time period (i.e., 01:30, 10:30, 13:30, or 22:30). $\overline{L S T}_{i, m, t}^{U}$ represents the average surface temperature of urban land in a city for the same period (Table A2). $\overline{L S T}_{i, m, t}^{R}$ represents the average surface temperature for the same period in a $10 \mathrm{~km}$ buffer zone around the city (Table A2). The water body pixels within the buffer zone and the pixels with an elevation more than $50 \mathrm{~m}$ above the highest point in the city were excluded from this analysis to avoid the influences from water and difference in elevation according to Zhou et al. [38].

Yearly, seasonal and monthly UHII for the entire region and the three zone of China, DPRK and Russia were calculated using Equations (2)-(5):

$$
U H I I_{R}=\sum_{S} U H I I_{R, S} / 4
$$


where, $U H I I_{R}$ represents the average annual UHII in the $R$-th region. The denominator of 4 denotes the number of seasons, $U H I I_{R, S}$ represents the average UHII of the $R$-th region in the $S$ season, which was expressed as:

$$
U H I I_{R, S}=\sum_{m} U H I I_{R, S, m} / 3
$$

where, the denominator of 3 denotes the number of months in one season, $U H I I_{R, S, m}$ represents the average UHII of the $R$-th region in the $m$-th month of the $S$ season, which was expressed as:

$$
U H I I_{R, S, m}=\sum_{t} U H I I_{R, S, m, t} / 4
$$

where, the denominator of 4 denotes the number of time periods (i.e., 01:30, 10:30, 13:30, or 22:30), $U H I I_{R, S, m, t}$ represents the average UHII of the $R$-th region in the $t$-th period of the $m$-th month, which was expressed as:

$$
U H I I_{R, S, m, t}=\sum_{i} U H I I_{R, S, m, t, i} / I
$$

where, $U H I I_{R, S, m, t, i}$ represents the UHII information of the $i$-th city in the $R$-th region, and $I$ represent the total number of cities in the $R$-th region. In this region, the Spring includes March, April, and May, the Summer includes June, July, and August, the Autumn includes September, October, and November, while the Winter includes December, January, and February.

The methods of Peng et al. [31] and Zhou et al. [39] were used to analyze the factors that influence the intensities of regional urban heat islands, with seasonal and daily changes in intensities used as basic analytical units. Eight variables were selected, including differences in NDVI, WSA and DEM values between urban and rural environments, geographical distance from the ocean, total area of urban land use, urban population density and urban nighttime light intensities. Both Pearson and Spearman correlation analysis methods were used to quantify the relationships between these factors and the UHII during different seasons and time periods.

\section{Results}

\subsection{Spatial Pattern of UHII in 2016}

The average UHII in the entire region in 2016 was $0.98{ }^{\circ} \mathrm{C}$, with intensity levels in summer significantly higher than levels during other seasons (Figure 2a). The average UHII in the entire region throughout the summer was $1.70{ }^{\circ} \mathrm{C}$, with average intensities throughout the other three seasons between $0.49-0.94{ }^{\circ} \mathrm{C}$ (Table 1 ). The UHII in the entire region varied significantly, with intensity levels reaching a highest value of $1.81{ }^{\circ} \mathrm{C}$ in July, with the lowest value of $0.40{ }^{\circ} \mathrm{C}$ occurring in January (Figure 2b, Table 2).

The daily UHII in the entire region was significantly higher than during the night (Figure 2c), with average UHII at $10: 30$ and $13: 30$ of $1.16^{\circ} \mathrm{C}$ and $1.46^{\circ} \mathrm{C}$ and average UHII at 22:30 and 1:30 of $0.68{ }^{\circ} \mathrm{C}$ and $0.65^{\circ} \mathrm{C}$, respectively (Table 3). The UHII during the day were found to be around 2 times the values that occurred during the night. UHII at $13: 30$ in July was the highest at $3.03{ }^{\circ} \mathrm{C}$, with the UHII at 10:30 in January being the lowest at $0.19^{\circ} \mathrm{C}$, corresponding to a difference of $2.84^{\circ} \mathrm{C}$ (Figure 2d, Table 3).

Table 1. Average Urban Heat Island Intensity (UHII) for different seasons in 2016.

\begin{tabular}{cccccc}
\hline Range & Spring $\left({ }^{\circ} \mathbf{C}\right)$ & Summer $\left({ }^{\circ} \mathbf{C}\right)$ & Autumn $\left({ }^{\circ} \mathbf{C}\right)$ & Winter $\left({ }^{\circ} \mathbf{C}\right)$ & Annual $\left({ }^{\circ} \mathbf{C}\right)$ \\
\hline The entire region & 0.94 & 1.70 & 0.81 & 0.49 & 0.98 \\
China & 1.12 & 2.08 & 0.80 & 0.39 & 1.10 \\
Russia & 0.94 & 1.57 & 0.99 & 0.81 & 1.08 \\
DPRK & 0.75 & 1.45 & 0.63 & 0.29 & 0.78 \\
\hline
\end{tabular}


Table 2. UHII for different months in 2016.

\begin{tabular}{|c|c|c|c|c|c|c|c|c|c|c|c|c|}
\hline Range & $\begin{array}{c}\text { January } \\
\left({ }^{\circ} \mathrm{C}\right)\end{array}$ & $\begin{array}{c}\text { February } \\
\left({ }^{\circ} \mathrm{C}\right)\end{array}$ & $\begin{array}{c}\text { March } \\
\left({ }^{\circ} \mathrm{C}\right)\end{array}$ & $\begin{array}{c}\text { April } \\
\left({ }^{\circ} \mathrm{C}\right)\end{array}$ & $\begin{array}{l}\text { May } \\
\left({ }^{\circ} \mathrm{C}\right)\end{array}$ & $\begin{array}{l}\text { June } \\
\left({ }^{\circ} \mathrm{C}\right)\end{array}$ & $\begin{array}{l}\text { July } \\
\left({ }^{\circ} \mathrm{C}\right)\end{array}$ & $\begin{array}{c}\text { August } \\
\left({ }^{\circ} \mathrm{C}\right)\end{array}$ & $\begin{array}{c}\text { September } \\
\left({ }^{\circ} \mathrm{C}\right)\end{array}$ & $\begin{array}{c}\text { October } \\
\left({ }^{\circ} \mathrm{C}\right)\end{array}$ & $\begin{array}{c}\text { November } \\
\left({ }^{\circ} \mathrm{C}\right)\end{array}$ & $\begin{array}{c}\text { December } \\
\left({ }^{\circ} \mathrm{C}\right)\end{array}$ \\
\hline The entire region & 0.40 & 0.61 & 0.73 & 0.89 & 1.18 & 1.57 & 1.81 & 1.72 & 1.14 & 0.69 & 0.59 & 0.47 \\
\hline China & 0.35 & 0.48 & 0.90 & 1.08 & 1.39 & 1.95 & 2.17 & 2.12 & 1.26 & 0.66 & 0.47 & 0.34 \\
\hline Russia & 0.80 & 0.83 & 0.73 & 0.87 & 1.21 & 1.46 & 1.66 & 1.59 & 1.39 & 0.83 & 0.75 & 0.79 \\
\hline DPRK & 0.06 & 0.53 & 0.57 & 0.74 & 0.95 & 1.31 & 1.61 & 1.44 & 0.76 & 0.58 & 0.56 & 0.27 \\
\hline
\end{tabular}

Table 3. UHII at different times in 2016.

\begin{tabular}{ccccc}
\hline Range & $\mathbf{1 0 : 3 0}\left({ }^{\circ} \mathbf{C}\right)$ & $\mathbf{1 3 : 3 0}\left({ }^{\circ} \mathbf{C}\right)$ & $\mathbf{2 2 : 3 0}\left({ }^{\circ} \mathbf{C}\right)$ & $\mathbf{1 : 3 0}\left({ }^{\circ} \mathbf{C}\right)$ \\
\hline The entire region & 1.16 & 1.46 & 0.68 & 0.65 \\
China & 1.37 & 1.57 & 0.76 & 0.69 \\
Russia & 1.23 & 1.57 & 0.78 & 0.71 \\
DPRK & 0.86 & 1.24 & 0.48 & 0.54 \\
\hline
\end{tabular}
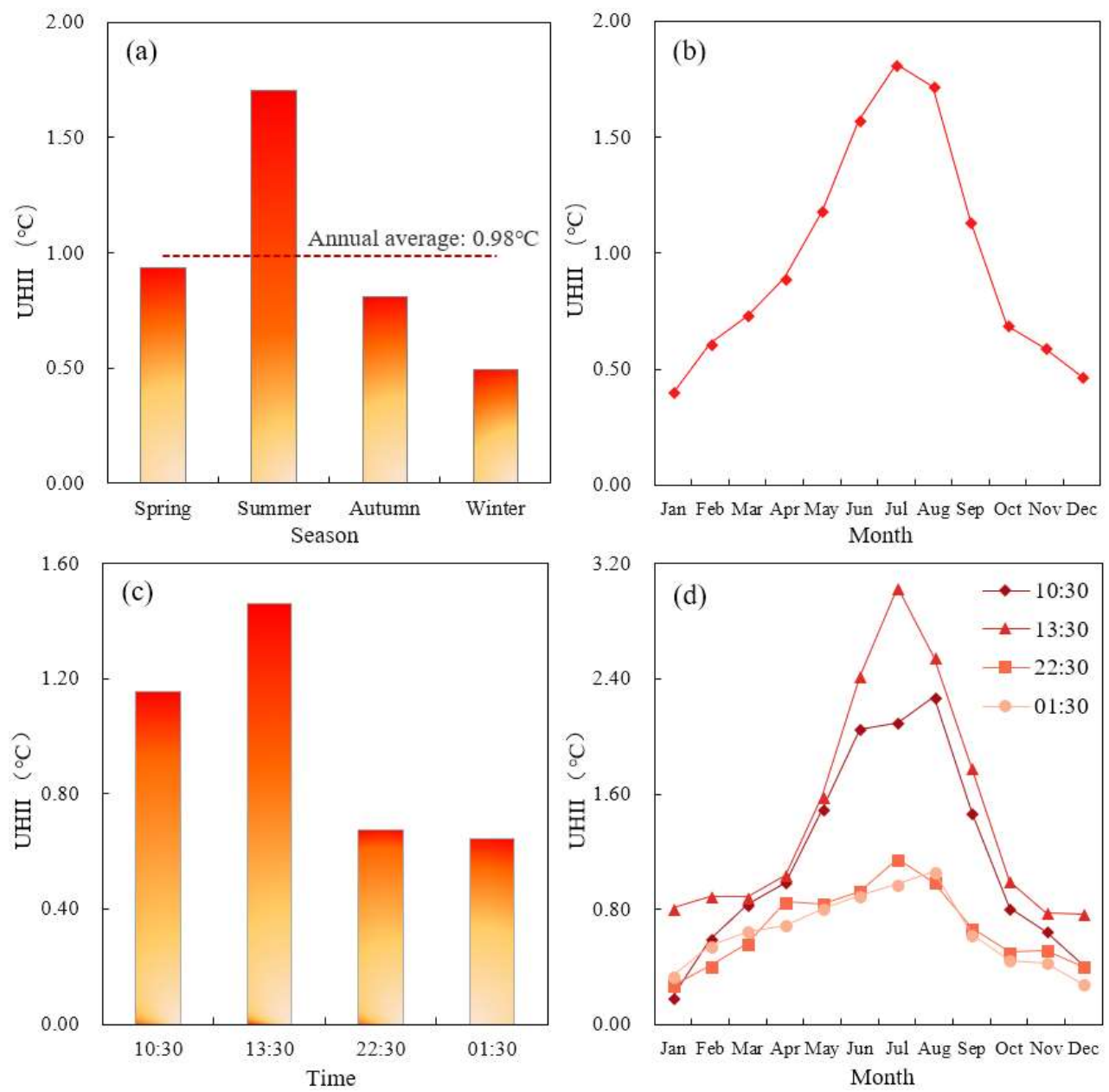

Figure 2. Spatial pattern of UHII in 2016: (a) Annual and seasonal UHII; (b) Monthly UHII; (c) UHII at different times of the day; (d) UHII at different times of each month.

\subsection{Spatial Pattern of UHII in Chinese, DPRK and Russian Regions in 2016}

The annual UHII on the Chinese side was greater than those on the other two sides (Figure 3a). In 2016, average UHII were $1.10^{\circ} \mathrm{C}$ in China, $1.08{ }^{\circ} \mathrm{C}$ in Russia and $0.78^{\circ} \mathrm{C}$ in DPRK across the study area (Table 1). Therefore, the average UHII on the Chinese side was $0.02{ }^{\circ} \mathrm{C}$ higher than on the Russian side and $0.32{ }^{\circ} \mathrm{C}$ higher than on the side in DPRK (Table 1). 
The UHII in the region of China, DPRK, and Russia varied significantly over the four seasons (Tables 1 and 2, Figure 3b). In spring and summer, the UHII on the Chinese side was highest, with values of $1.12{ }^{\circ} \mathrm{C}$ and $2.08{ }^{\circ} \mathrm{C}$, respectively. The UHII on the side of DPRK were lowest, with average values of $0.75{ }^{\circ} \mathrm{C}$ and $1.45{ }^{\circ} \mathrm{C}$, respectively. In autumn and winter, the UHII on the Russian side were the highest at $0.99^{\circ} \mathrm{C}$ and $0.81^{\circ} \mathrm{C}$, with intensities on the side of DPRK being the lowest at $0.63{ }^{\circ} \mathrm{C}$ and $0.29^{\circ} \mathrm{C}$ (Table 1). The UHII on the Russian side during January-February were the highest, with temperatures being higher by around $0.7^{\circ} \mathrm{C}$ (Figure 3c). The UHII on the Chinese side during March to August were higher than $1.0^{\circ} \mathrm{C}$, with the Russian side having intensity levels greater than $0.7^{\circ} \mathrm{C}$ from September to December (Figure 3c, Table 2).

The differences in UHII in the region of China, DPRK, and Russia was greatest during the day (Figure 3d). At 10:30, the UHII on the Chinese side was highest at $1.37^{\circ} \mathrm{C}$, with the side in DPRK affording the lowest value at $0.86{ }^{\circ} \mathrm{C}$, corresponding to a temperature difference of $0.51{ }^{\circ} \mathrm{C}$ between the two sides (Table 3). At 13:30, the UHII on the Chinese and Russian sides were the highest at $1.57^{\circ} \mathrm{C}$, with the side in DPRK the lowest at $1.24{ }^{\circ} \mathrm{C}$, corresponding to a difference of $0.33^{\circ} \mathrm{C}$. At 22:30, the UHII on the Russian side was the highest at $0.78^{\circ} \mathrm{C}$, with the side in DPRK the lowest at $0.48^{\circ} \mathrm{C}$, corresponding to a difference of $0.30^{\circ} \mathrm{C}$. The UHII on the Russian side at 01:30 was the highest at $0.71{ }^{\circ} \mathrm{C}$, with the side in DPRK the lowest at $0.54^{\circ} \mathrm{C}$, corresponding to a difference of $0.17^{\circ} \mathrm{C}$ (Table 3).
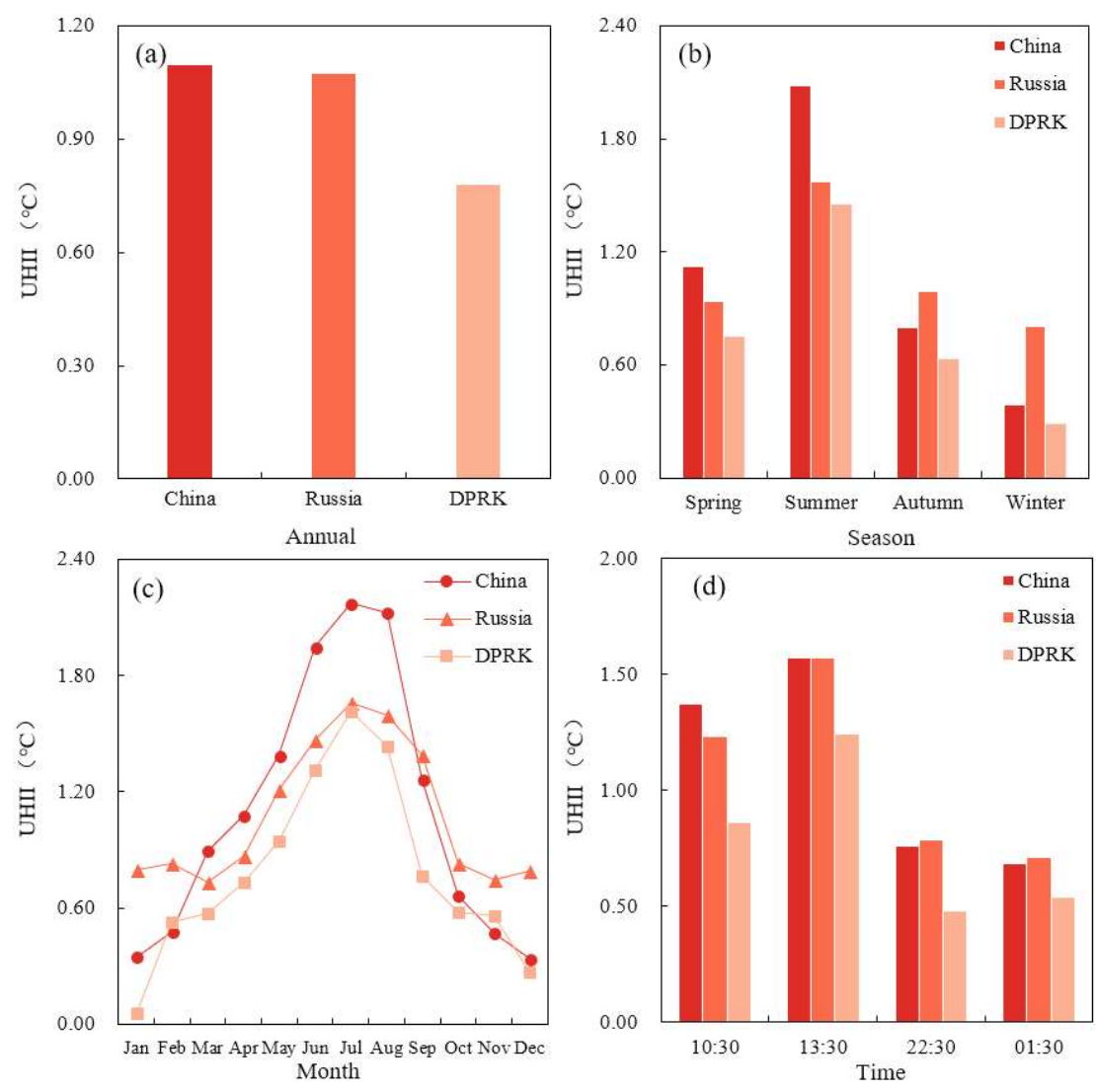

Figure 3. Spatial pattern of UHII in the region of China, Democratic People's Republic of Korea (DPRK), and Russia in 2016: (a) Annual UHII; (b) UHII for different seasons; (c) UHII for different months; (d) Different UHII at different times of the day.

\subsection{Factors Affecting UHII}

The UHII in the summer and winter were not significantly correlated, indicating that different seasonal factors were affecting intensity levels throughout the year (Table 4, Table A3). In addition, the UHII in the daytime and nighttime were not significantly correlated as well, indicating the factors affecting UHII were diverse in the different periods (Table 4, Table A3). 
The UHII in the region during the summer day were significantly correlated to NDVI, urban land area, total urban population, and night-time light intensities of cities (Table 5, Table A4). Correlation coefficients between the UHII and the total population of cities and between UHII and urban land area were the highest at 0.76 , which passed a significance test at a 0.01 level. The correlation coefficients between urban nighttime light intensity and UHII was 0.67 , which also passed a 0.01 level significance test. The correlation coefficient between UHII and $\Delta$ NDVI was 0.57 , passing a 0.05 level significance level. This correlation analysis shows that larger cities, higher levels of social and economic development, and lower coverage by urban vegetation results in urban heat islands with higher intensities.

Table 4. Pearson's correlation coefficients of UHII for different seasons and time periods.

\begin{tabular}{|c|c|c|c|c|c|c|c|c|}
\hline \multirow{2}{*}{\multicolumn{2}{|c|}{ Variables }} & \multicolumn{4}{|c|}{ Day } & \multicolumn{3}{|c|}{ Night } \\
\hline & & Spring & Summer & Autumn & Winter & Spring & Summer & Autumn \\
\hline \multirow{3}{*}{ Day } & Summer & $0.83 * *$ & & & & & & \\
\hline & Autumn & $0.73 * *$ & $0.86^{* *}$ & & & & & \\
\hline & Winter & 0.14 & 0.24 & 0.39 & & & & \\
\hline \multirow{4}{*}{ Night } & Spring & -0.34 & 0.10 & 0.24 & 0.49 * & & & \\
\hline & Summer & -0.25 & 0.17 & 0.16 & $0.61^{* *}$ & $0.82 * *$ & & \\
\hline & Autumn & $-0.64^{* *}$ & -0.25 & -0.03 & 0.32 & $0.87^{* *}$ & $0.61^{* *}$ & \\
\hline & Winter & $-0.57^{*}$ & -0.27 & 0.03 & 0.34 & $0.81^{* *}$ & 0.50 * & $0.94^{* *}$ \\
\hline
\end{tabular}

Table 5. Pearson's correlation analysis of UHII and various influencing factors.

\begin{tabular}{|c|c|c|c|c|c|c|c|c|c|}
\hline \multicolumn{2}{|c|}{ Variables } & $\Delta$ NDVI & $\Delta \mathrm{WSA}$ & DEM & $\begin{array}{l}\text { Distance } \\
\text { from the } \\
\text { Ocean }\end{array}$ & $\begin{array}{l}\text { Urban } \\
\text { Land } \\
\text { Area }\end{array}$ & $\begin{array}{c}\text { Urban } \\
\text { Population }\end{array}$ & $\begin{array}{c}\text { Urban } \\
\text { Population } \\
\text { Density }\end{array}$ & $\begin{array}{c}\text { Urban } \\
\text { Nighttime } \\
\text { Light Intensity }\end{array}$ \\
\hline \multirow{5}{*}{ Day } & Spring & -0.35 & 0.33 & 0.26 & 0.11 & 0.42 & 0.38 & -0.05 & $0.45^{*}$ \\
\hline & Summer & $-0.57^{*}$ & 0.35 & 0.07 & 0.06 & $0.76^{* *}$ & $0.76^{* *}$ & 0.04 & $0.67 * *$ \\
\hline & Autumn & $-0.50 *$ & 0.09 & 0.06 & -0.04 & $0.76^{* *}$ & $0.77^{* *}$ & -0.06 & $0.82 * *$ \\
\hline & Winter & -0.18 & 0.04 & -0.01 & -0.26 & 0.38 & 0.29 & 0.03 & $0.60 * *$ \\
\hline & Annual & $-0.51^{*}$ & 0.29 & 0.14 & 0.01 & $0.69^{* *}$ & $0.67^{* *}$ & -0.01 & $0.73 * *$ \\
\hline \multirow{5}{*}{ Night } & Spring & -0.10 & 0.13 & -0.11 & -0.04 & $0.44^{*}$ & $0.48^{*}$ & 0.02 & 0.38 \\
\hline & Summer & $-0.70 * *$ & $0.51 *$ & 0.12 & 0.21 & 0.50 * & $0.52 *$ & 0.18 & 0.29 \\
\hline & Autumn & -0.28 & 0.17 & -0.33 & -0.27 & 0.17 & 0.22 & -0.06 & 0.19 \\
\hline & Winter & 0.14 & 0.08 & -0.35 & -0.30 & 0.08 & 0.11 & -0.06 & 0.22 \\
\hline & Annual & -0.27 & 0.02 & -0.23 & -0.16 & 0.28 & 0.31 & 0.01 & 0.28 \\
\hline
\end{tabular}

Note: ${ }^{* *} p<0.01 ; * p<0.05 . \Delta$ NDVI is the average NDVI for urban land minus the average NDVI in a $10 \mathrm{~km}$ buffer zone surrounding each urban land zone. $\triangle$ WSA is the mean value of urban land WSA minus the average WSA within the $10 \mathrm{~km}$ buffer zone.

The findings from this study are consistent with previous reports by Zipper et al. [40], who found that the UHII were closely correlated to differences in vegetation coverage between urban and rural areas. Jenerette et al. [41] also found that increases in urban population resulted in an increase in intensity of urban heat island effects, with vegetation thought to reduce surface temperatures through transpiration processes. Therefore, a lower degree of urban vegetation coverage [42-45] and urban population growth can lead to increases in anthropogenic heat emissions $[7,46,47]$ resulting in urban heat islands with higher intensities.

\section{Discussions}

\subsection{Impact of Urban Heat Island Effects on Residents' Health}

Urban heat island effects lead to an increase in urban temperatures that can cause high-temperature heat waves in the summer that increase children's skin allergies and the incidence of 
heart disease amongst the elderly [48-50]. In addition, increased numbers of pollutants accumulate in heat island centers, which can directly stimulate people's respiratory mucosa that can result in the onset of respiratory diseases [51-53].

Urban heat island effects result in a trend towards increasing maximum summer temperatures and greater numbers of high-temperature days in Chinese cities in this area. Using Hunchun as an example, the maximum temperature in summer in this city increased from $33{ }^{\circ} \mathrm{C}$ in 2011 to $34{ }^{\circ} \mathrm{C}$ in 2017, corresponding to an average annual increase of $0.03^{\circ} \mathrm{C}$ (Figure 4a), reaching a high of $36^{\circ} \mathrm{C}$ in 2016. At the same time, the number of high-temperature days above $32{ }^{\circ} \mathrm{C}$ increased from 7 days in 2011 to 14 days in 2017, with an average annual increase over this period of around 1 day (Figure 4b).

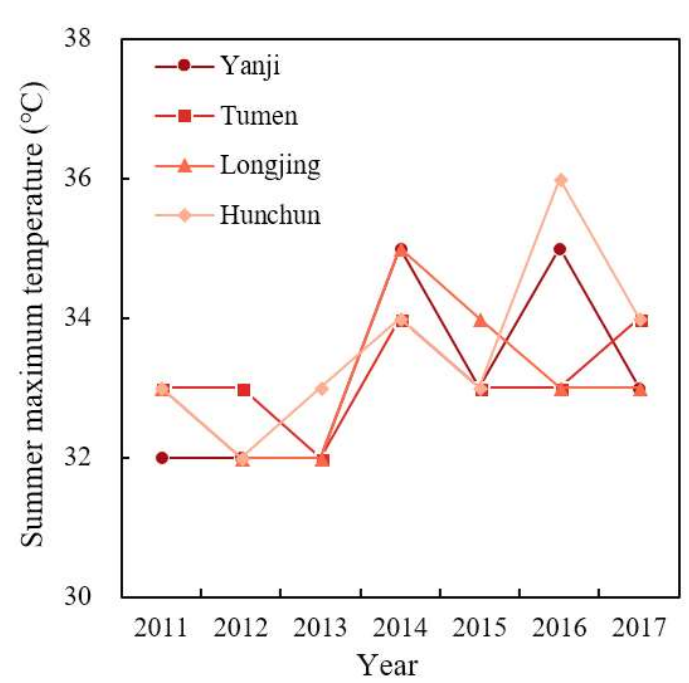

(a)

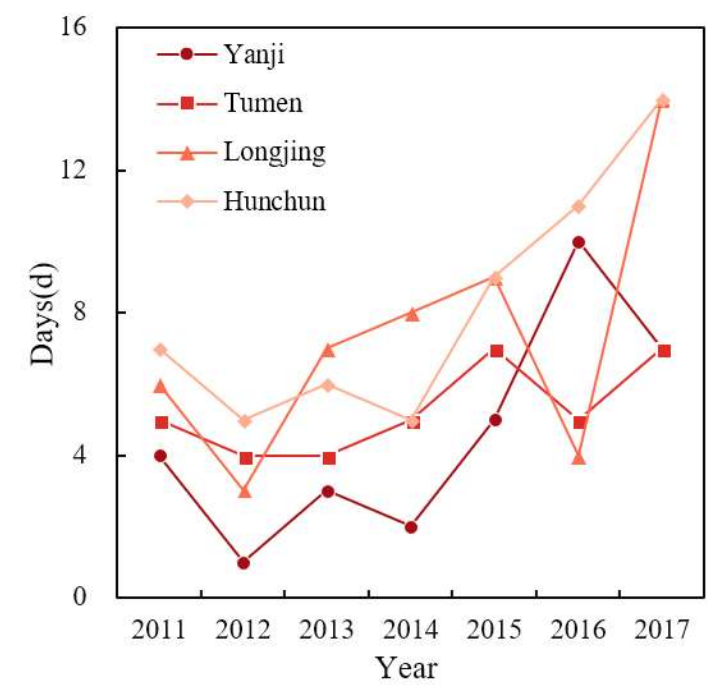

(b)

Figure 4. Changes in maximum temperatures and the number of high-temperature days recorded during the summer in 2011-2017 in the Chinese cities, including Yanji City, Tumen City, Longjing City, and Hunchun City: (a) maximum temperatures; (b) number of high-temperature days. Note: Only the temperatures of 4 cities in China were analyzed due to availability of data. High temperature days were counted when the maximum daily temperature exceeded $32{ }^{\circ} \mathrm{C}$.

To understand the influences of urban heat island effect on residents' health, we first conducted face-to-face interviews and questionnaires with 211 residents under different age from 5 July to 10 July in 2018 in Yanji City, the largest city in our study area, and then analyzed the data on deaths from 2010 to 2014 acquired from the Center for Disease Control and Prevention in the same city (Figure 5). We found that $67.77 \%$ of respondents were affected by the high temperature in summer due to urban heat island effects (Figure $5 \mathrm{a}$ ), and more than $20 \%$ of respondents replied that the high temperature resulted in physical discomfort, insomnia, inappetence, heat stroke, respiratory diseases, and decreasing outdoor activities (Figure $5 b$ ). In addition, the population and proportion of deaths due to diseases related to high temperature in summer-mainly including hypertension, cardiomyopathy, and asthma-both showed an increasing trend from 2010 to 2014 in Yanji City (Figure 5c). Thus, the urban heat island effect has been an important factor impacting residents' health.

In addition, the total population of elderly and children, which are susceptible to high temperature in summer, on the sides in China and DPRK in recent years both show an increasing trend. From 2000 to 2015, the total population of elderly on the Chinese side increased from 157,000 to 173,000 , corresponding to an increase of $10.19 \%$, whilst the total number of children increased from 27,500 to 30,300 , corresponding to an increase of $10.18 \%$. The total population of elderly on the side in DPRK increased from 66,100 to 71,700 , corresponding to an increase of $8.47 \%$, whilst the total number of children increased from 45,400 to 49,200 , corresponding to an increase of $8.37 \%$ (Figure 6). 
(a)

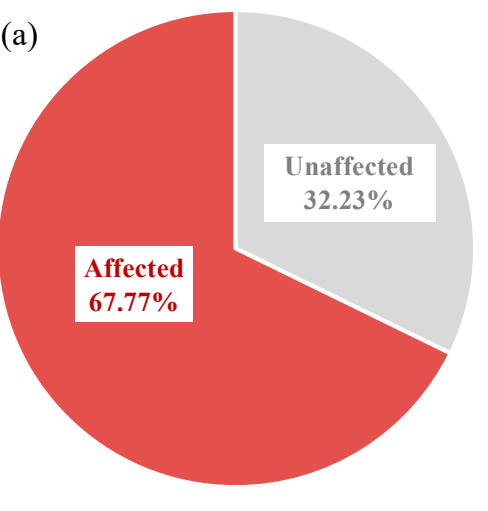

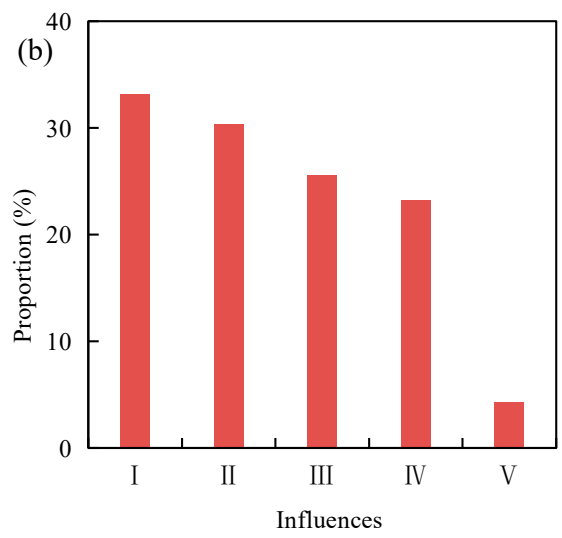

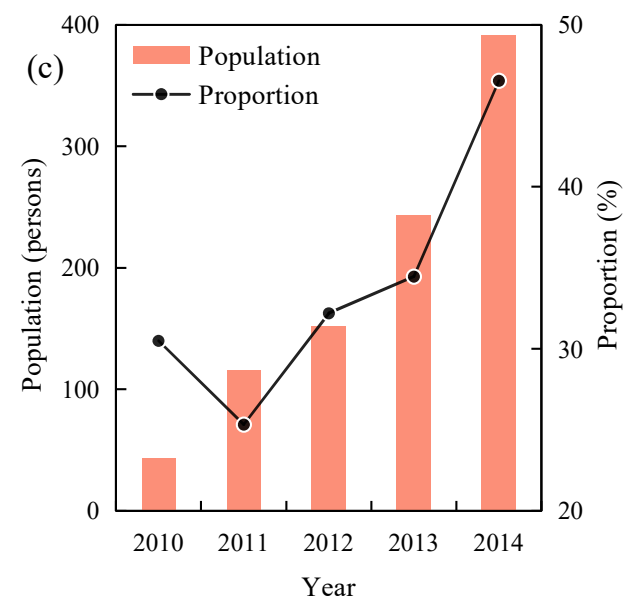

Figure 5. Influences of urban heat island effects on residents in Yanji City: (a) proportion of affected respondents; (b) proportion of respondents with different influences *; (c) population and proportion of deaths due to diseases related to high temperature in summer ${ }^{* *}$. Note: Only the influences in Yanji City were analyzed due to availability of data. * I: physical discomfort, II: insomnia, inappetence or heat stroke, III: respiratory diseases, IV: decreasing outdoor activities, V: other influences. ${ }^{* *}$ The diseases related to high temperature in summer mainly include hypertension, cardiopathy, and asthma.
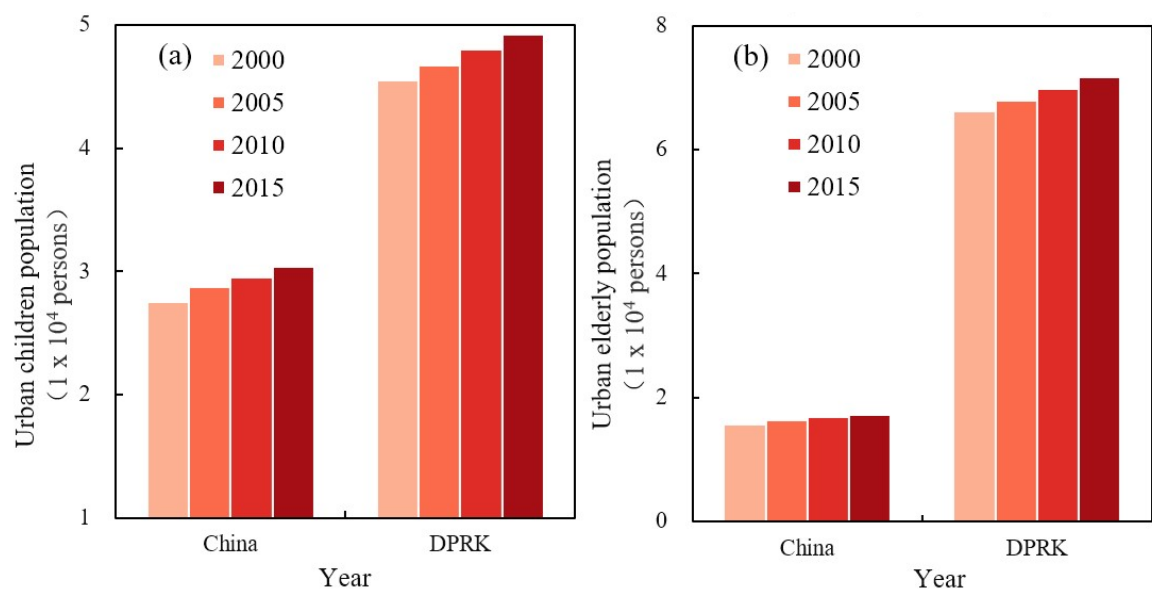

Figure 6. Changes in the total population of children and elderly people from 2000 to 2015 in the region of China and DPRK of the TUATR: (a) changes in population of children; (b) changes in population of the elderly. Note: Due to the limited availability of data, only population distributions for children and elderly people in the region of China and DPRK were analyzed. 
Rapid urbanization of the region and global warming are likely to increase the intensity of urban heat island effects in the TUATR, which will result in an increased threat to the health of residents $[5,22,54]$. Therefore, it is recommended that future urbanization policies attempt to reduce the impact of urban heat island effects in this region by increasing urban green space, controlling the development of cities and reducing urban anthropogenic heat emissions. Ultimately, any reduction in the impact of urban heat islands on local temperatures in these cities is likely to have a positive impact on the health and well-being of its residents.

\subsection{Future Perspectives}

This study has analyzed the spatial pattern of UHII across the TUATR using the cloud-free observations of LST, which resulted in data deficient in some periods. To limit the influences of data deficient, we performed monthly composition according to Wan et al. [35]. Thus, the variances of UHII intra-month have not been analyzed in this study. In addition, we used both of the Pearson's correlation and the Spearman's correlation to analyze the relationships of UHII for different seasons and time periods as well as the factors influencing UHII (Tables 4 and 5, Tables A3 and A4). We found that the two approaches would result in different correlations in some cases. For example, the daytime UHII in Spring had significantly negative correlation with the nighttime UHII in Autumn as a result of Pearson's correlation (Table 4), whereas they were not significantly correlated according to Spearman's correlation analysis (Table A3). In terms of the mechanism, such significant relationship for different time periods in different seasons cannot be well explained. This highlighted that utilization of multiple statistical approaches can help us to validate results between each other.

Future research will concentrate on using remote sensing ASTER and Landsat data with relatively high resolution [55] to analyze annual urban heat island variations and the impact of urban morphology on their intensities. This data will also be used to examine the influence of green space on UHII and use this information to produce effective guidelines to optimize urban land use and the sustainability of cities [56].

\section{Conclusions}

Landsat images and MODIS LST data have been used to quantify spatial patterns of UHII across the TUATR in 2016. The average UHII in this region was found to be $1.0^{\circ} \mathrm{C}$, with the highest intensity of $3.0^{\circ} \mathrm{C}$ occurring in the daytime during summer. The UHII on the Chinese side were significantly higher than those on the sides in DPRK and Russia, with intensities influenced by a number of factors including the size of their cities, social and economic activities, and vegetation coverage. Urban heat island effects resulted in maximum summer temperatures and the number of high-temperature days in Chinese cities being increased significantly, thus posing a potential threat to the health and wellbeing of their residents. Therefore, the UHII in this region should be reduced by increasing the number of green spaces present, controlling the sizes of cities, and reducing urban anthropogenic heat emission levels. All of these measures would contribute significantly to increasing the sustainability of its regional cities and improving the quality of life of its residents.

Author Contributions: B.L. and Z.L. collected and processed the data, performed analysis and wrote the paper. Y.N. and Z.L. conceived and designed the study and wrote the paper. All authors reviewed and edited the draft, approved the submitted manuscript, and agreed to be listed and accepted the version for publication.

Funding: National Natural Science Foundation of China [Grant Number 4177010220].

Acknowledgments: We would like to thank Qun Ma from Beijing Normal University for her helpful suggestions. We also want to express our respects and gratitude to the anonymous reviewers and editors for their professional comments and suggestions. This work has been supported in part by the National Natural Science Foundation of China [Grant Number 4177010220].

Conflicts of Interest: The authors declare no conflict of interest. 


\section{Appendix A}

Text A1. The extraction of urban land.

Presently, three main types of method are used to extract urban land from remote sensing images, including unsupervised classification, supervised classification, and visual interpretation. Although the visual interpretation requires a large amount of human resources, it shows high accuracy and reliability. Thus, we extracted urban land from the Landsat data in 2016 through visual interpretation. First, we developed interpretation criteria for each land use/cover type based on combination of Landsat bands, the sampling points from field survey data [36]. These land use/cover types included coniferous forest, broadleaf forest, mixed forest, alpine birch forest, grassland, paddy field, dry farmland, water, marshland, bare land, urban land, and alpine tundra. The interpretation criteria included the features on spectrum, shape, and texture as well as the mainly distributed area, and were developed by identifying such features of sampling points from field survey in terms of different land use/cover types. Second, we performed a visual-interpretation-based land use/cover classification of Landsat data using the interpretation criteria to obtain the spatial patterns of each land use/cover type in 2016. During the visual interpretation, the standard false color composite images based on green, red, and near-infrared bands were primarily used as references, while the information on short wave infrared band were used as supplement. We identified the land use/cover type pixel by pixel according to the differences on spectral characteristics and the shape and texture features among various land use/cover types. Finally, we extracted urban land from the obtained land use/cover data.

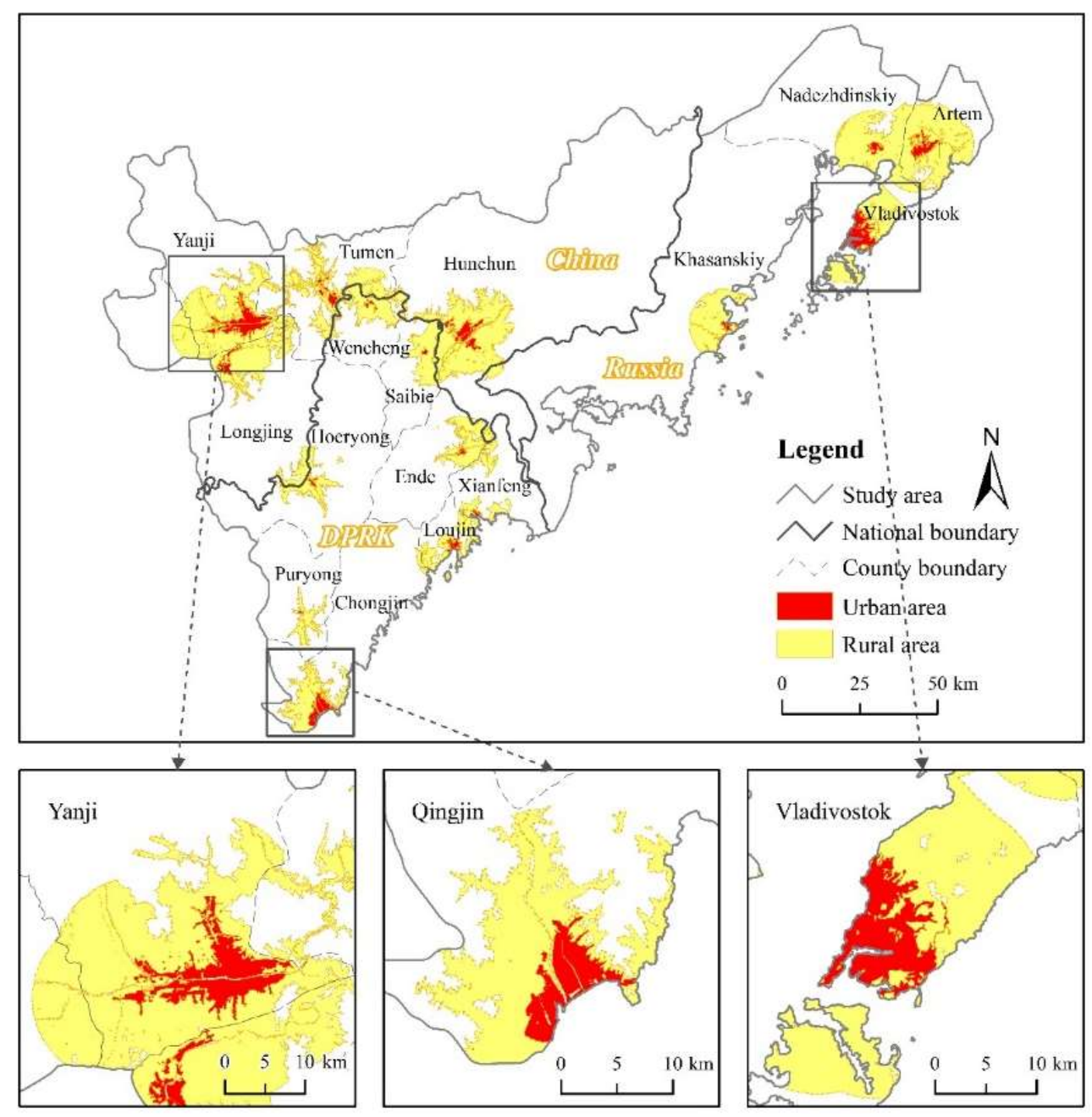

Figure A1. The urban area and buffer zone (rural area) used in this study. 
Table A1. Specific information on the Landsat data used in this study.

\begin{tabular}{cccc}
\hline Satellite & Sensor & Path/Row & Date \\
\hline & & $114 / 30$ & 12 October 2016 \\
Landsat 8 & OLI & $114 / 31$ & 12 October 2016 \\
& & $115 / 30$ & 28 May 2016 \\
& & $115 / 31$ & 28 May 2016 \\
\hline
\end{tabular}

Table A2. The urban and rural pixels used for the analysis in this study.

\begin{tabular}{cccc}
\hline Region & City & Urban Pixels * & Rural Pixels * \\
\hline \multirow{4}{*}{ China } & Yanji & 91,698 & 454,056 \\
& Longjing & 19,281 & 416,903 \\
& Tumen & 15,901 & 292,133 \\
& Hunchun & 44,600 & 530,119 \\
\hline \multirow{4}{*}{ Russia } & Artem & 35,466 & 450,528 \\
& Nadezhdinskiy & 12,297 & 350,451 \\
& Vladivostok & 75,401 & 281,511 \\
& Khasanskiy & 6648 & 255,153 \\
\hline \multirow{5}{*}{ DPRK } & Chongin & 37,334 & 198,724 \\
& Puryong & 1174 & 64,693 \\
& Luojin & 12,007 & 120,927 \\
& Ende & 4555 & 136,380 \\
& Hoeryong & 3866 & 96,158 \\
& Saibie & 2673 & 139,296 \\
& Xianfeng & 3506 & 90,023 \\
& Wencheng & 4225 & 148,747 \\
\hline \multicolumn{4}{c}{ Note: ${ }^{*}$ The pixel size is $30 \times 30 \mathrm{~m}^{2}}$. \\
\hline
\end{tabular}

Table A3. Spearman's correlation coefficients of UHII for different seasons and time periods.

\begin{tabular}{|c|c|c|c|c|c|c|c|c|}
\hline \multirow{2}{*}{\multicolumn{2}{|c|}{ Variables }} & \multicolumn{4}{|c|}{ Day } & \multicolumn{3}{|c|}{ Night } \\
\hline & & Spring & Summer & Autumn & Winter & Spring & Summer & Autumn \\
\hline \multirow{3}{*}{ Day } & Summer & $0.67^{* *}$ & & & & & & \\
\hline & Autumn & $0.61 * *$ & $0.91^{* *}$ & & & & & \\
\hline & Winter & 0.03 & -0.01 & -0.05 & & & & \\
\hline \multirow{4}{*}{ Night } & Spring & -0.34 & 0.14 & 0.14 & $0.46^{*}$ & & & \\
\hline & Summer & -0.22 & 0.25 & 0.18 & 0.40 & $0.82 * *$ & & \\
\hline & Autumn & -0.36 & 0.14 & 0.15 & 0.38 & $0.92 * *$ & $0.69 * *$ & \\
\hline & Winter & -0.33 & -0.02 & 0.09 & 0.38 & $0.79 * *$ & $0.60 * *$ & $0.88^{* *}$ \\
\hline
\end{tabular}

Table A4. Spearman's correlation Analysis of UHII and various influencing factors.

\begin{tabular}{|c|c|c|c|c|c|c|c|c|c|}
\hline \multicolumn{2}{|c|}{ Variables } & $\Delta$ NDVI & $\Delta \mathrm{WSA}$ & DEM & $\begin{array}{c}\text { Distance } \\
\text { from the } \\
\text { Ocean }\end{array}$ & $\begin{array}{l}\text { Urban } \\
\text { Land } \\
\text { Area }\end{array}$ & $\begin{array}{c}\text { Urban } \\
\text { Population }\end{array}$ & $\begin{array}{c}\text { Urban } \\
\text { Population } \\
\text { Density }\end{array}$ & $\begin{array}{c}\text { Urban } \\
\text { Nighttime } \\
\text { Light Intensity }\end{array}$ \\
\hline \multirow{5}{*}{ Day } & Spring & $-0.45^{*}$ & 0.32 & 0.30 & 0.06 & 0.28 & 0.28 & -0.15 & 0.30 \\
\hline & Summer & $-0.66^{* *}$ & 0.24 & 0.12 & 0.08 & $0.80^{* *}$ & $0.84^{* *}$ & -0.11 & $0.67^{* *}$ \\
\hline & Autumn & $-0.50 *$ & 0.10 & 0.22 & 0.13 & $0.70^{* *}$ & 0.72 ** & -0.12 & 0.53 * \\
\hline & Winter & -0.01 & 0.07 & 0.07 & -0.18 & 0.08 & -0.03 & 0.02 & 0.36 \\
\hline & Annual & $-0.55^{*}$ & 0.20 & 0.18 & 0.06 & $0.63^{* *}$ & $0.63^{* *}$ & -0.20 & $0.55^{*}$ \\
\hline \multirow{5}{*}{ Night } & Spring & -0.13 & 0.06 & -0.14 & -0.19 & 0.31 & 0.27 & -0.01 & 0.41 \\
\hline & Summer & $-0.70^{* *}$ & $0.60^{* *}$ & -0.12 & -0.08 & 0.28 & 0.35 & 0.10 & 0.34 \\
\hline & Autumn & -0.44 & 0.21 & -0.37 & -0.44 & 0.29 & 0.29 & 0.01 & 0.33 \\
\hline & Winter & 0.13 & 0.03 & -0.34 & -0.44 & 0.04 & 0.03 & 0.01 & 0.06 \\
\hline & Annual & -0.30 & 0.15 & -0.14 & -0.26 & 0.20 & 0.21 & 0.07 & 0.30 \\
\hline
\end{tabular}

Note: ${ }^{* *} p<0.01 ; * p<0.05 . \Delta$ NDVI are the average NDVI for urban land minus the average NDVI in a $10 \mathrm{~km}$ buffer zone surrounding each urban land zone. $\triangle \mathrm{WSA}$ is the mean value of urban land WSA minus the average WSA within the $10 \mathrm{~km}$ buffer zone. 


\section{References}

1. Oke, T.R. The energetic basis of the urban heat island. Q. J. R. Meteorol. Soc. 1982, 108, 1-24. [CrossRef]

2. Streutker, D.R. Satellite-measured growth of the urban heat island of Houston, Texas. Remote Sens. Environ. 2003, 85, 282-289. [CrossRef]

3. Wu, J. Urban sustainability: An inevitable goal of landscape research. Landsc. Ecol. 2010, 25, 1-4. [CrossRef]

4. Huang, W.; Li, J.; Guo, Q.; Mansaray, L.; Li, X.; Huang, J. A Satellite-Derived Climatological Analysis of Urban Heat Island over Shanghai during 2000-2013. Remote Sens. 2017, 9, 641. [CrossRef]

5. Kim, S.O. National Center for Agro-Meteorology, Seoul National University, Seoul, Republic of Korea, Mapping Monthly Temperature Normals Across North Korea at a Landscape Scale. Korean J. Agric. For. Meteorol. 2011, 13. [CrossRef]

6. Unger, J. Intra-urban relationship between surface geometry and urban heat island: Review and new approach. Clim. Res. 2004, 27, 253-264. [CrossRef]

7. Clinton, N.; Gong, P. MODIS detected surface urban heat islands and sinks: Global locations and controls. Remote Sens. Environ. 2013, 134, 294-304. [CrossRef]

8. Grimm, N.B.; Faeth, S.H.; Golubiewski, N.E.; Redman, C.L.; Wu, J.; Bai, X.; Briggs, J.M. Global change and the ecology of cities. Science 2008, 319, 756-760. [CrossRef] [PubMed]

9. Zheng, X.J.; Sun, P.; Zhu, W.H.; Xu, Z.; Fu, J.; Man, W.D.; Li, H.L.; Zhang, J.; Qin, L. Landscape dynamics and driving forces of wetlands in the Tumen River Basin of China over the past 50 years. Landsc. Ecol. Eng. 2017, 13, 1-14. [CrossRef]

10. Shi, B.; Gao, L.; Liu, C.; Wang, B.J. Observation and analysis of the urban heat island effect on soil in Nanjing, China. Environ. Earth Sci. 2012, 67, 215-229. [CrossRef]

11. Krehbiel, C.P.; Zhang, X.; Henebry, G.M. Impacts of thermal time on land surface phenology in urban areas. Remote Sens. 2017, 9, 499. [CrossRef]

12. Krehbiel, C.P.; Jackson, T.; Henebry, G.M. Web-Enabled Landsat Data time series for monitoring urban heat island impacts on land surface phenology. IEEE J. Sel. Top. Appl. Earth Obs. Remote Sens. 2016, 9, $2043-2050$. [CrossRef]

13. Knapp, S. Changes in the Functional Composition of a Central European Urban Flora over Three Centuries. Perspectives in Plant Ecology. Evol. Syst. 2010, 12, 235-244.

14. Kuznetsova, I.N.; Nakhaev, M.I.; Shalygina, I.Y.; Lezina, E.A. Meteorological prerequisites of formation of severe winter time air pollution episodes in Moscow. Russ. Meteorol. Hydrol. 2008, 33, 167-174. [CrossRef]

15. Ginzburg, A.S.; Vinogradova, A.A.; Fedorova, E.I.; Nikitich, E.V.; Karpov, A.V. Content of oxygen in the atmosphere over large cities and respiratory problems. Izv. Atmos. Ocean. Phys. 2014, 50, 782-792. [CrossRef]

16. Wong, K.V.; Paddon, A.; Jimenez, A. Review of world urban heat islands: Many linked to increased mortality. J. Energy Resour. Technol. 2013, 135, 82-90. [CrossRef]

17. Fang, C. The Strategy and Pattern of International Economic Cooperation in Tumen River Area of China under the Background of "the Belt and Road". Northeast Asia Econ. Res. 2017, 1, 5-14.

18. Lim, S.W.; Suthiwartnarueput, K.; Abareshi, A.; Lee, T.W.; Duval, Y. Key Factors in Developing Transit Trade Corridors in Northeast Asia. J. Korea Trade 2017, 21. [CrossRef]

19. Lee, N.J. Northeast Asian Economic Cooperation and the Korean Peninsula Economy: The Impact of the Changitu Development Plan. Korea J. 2011, 51, 130-163.

20. Mikhailov, R.V. Russian Mission in Asia. “Berdyaev Readings" in Vladivostok. Polis. Political Stud. 2015, 23-28. [CrossRef]

21. Gao, F.; Dai, X.; Li, B. Possible driving factors of urbanization and urban heat island in Northeast Plain of China. Clim. Environ. Res. 2012, 17, 353-364.

22. Holmer, B.; Eliasson, I. Urban-rural vapour pressure differences and their role in the development of urban heat islands. Int. J. Climatol. 2015, 19, 989-1009. [CrossRef]

23. Jan, E.; David, F.; Ulf, B.; Anne, V.; Rashitm, H.; Alexanderv, K. Trends and uncertainties in Siberian indicators of 20th century warming. Glob. Chang. Biol. 2010, 16, 386-398.

24. Zhang, Y.; Bai, Z.; Liu, W. Assessing the surface urban heat island effect in Xining, China. In Geo-Informatics in Resource Management and Sustainable Ecosystem; Springer: Berlin/Heidelberg, Germany, 2013; pp. $264-273$.

25. Hu, L.; Brunsell, N.A. The impact of temporal aggregation of land surface temperature data for surface urban heat island (SUHI) monitoring. Remote Sens. Environ. 2013, 134, 162-174. [CrossRef] 
26. Liu, W.; Feddema, J.; Hu, L.; Zung, A.; Brunsell, N. Seasonal and Diurnal Characteristics of Land Surface Temperature and Major Explanatory Factors in Harris County, Texas. Sustainability 2017, 9, 2324. [CrossRef]

27. Krehbiel, C.P.; Henebry, G.M. A comparison of multiple datasets for monitoring thermal time in urban areas over the U.S. Upper Midwest. Remote Sens. 2016, 8, 297. [CrossRef]

28. Zhao, L.; Lee, X.; Smith, R.; Oleson, K. Strong contributions of local background climate to urban heat islands. Nature 2014, 511, 216-219. [CrossRef] [PubMed]

29. Wan, Z. New refinements and validation of the MODIS land-surface temperature/emissivity products. Remote Sens. Environ. 2008, 112, 59-74. [CrossRef]

30. Wan, Z. New refinements and validation of the collection-6 MODIS land-surface temperature/emissivity product. Remote Sens. Environ. 2014, 140, 36-45. [CrossRef]

31. Peng, S.; Piao, S.; Ciais, P.; Friedlingstein, P.; Ottle, C.; Bréon, F.M.; Nan, H.; Zhou, L.; Myneni, R.B. Surface urban heat island across 419 global big cities. Environ. Sci. Technol. 2012, 46, 696-703. [CrossRef] [PubMed]

32. Meng, Q.; Zhang, L.; Sun, Z.; Meng, F.; Wang, L.; Sun, Y. Characterizing spatial and temporal trends of surface urban heat island effect in an urban main built-up area: A 12-year case study in Beijing, China. Remote Sens. Environ. 2018, 204, 826-837. [CrossRef]

33. Miles, V.; Esau, I. Seasonal and Spatial Characteristics of Urban Heat Islands (UHIs) in Northern West Siberian Cities. Remote Sens. 2017, 9, 989. [CrossRef]

34. Gao, W.; Zhu, C.; Wang, Y. Analysis on Characteristic of Hydrology and Meteorology for Tumenjiang Basin. Jilin Water Resour. 2000, 12, 22-24.

35. Wan, Z. Collection-5 MODIS Land Surface Temperature Products Users' Guide; ICESS, University of California: Santa Barbara, CA, USA, 2007.

36. Tao, H.; Nan, Y.; Liu, Z.F. Spatiotemporal Patterns of Forest in the Transnational Area of Changbai Mountain from 1977 to 2015: A Comparative Analysis of the Chinese and DPRK Sub-Regions. Sustainability 2017, 9 , 1054. [CrossRef]

37. Liu, Z.; He, C.; Zhou, Y.; Wu, J. How much of the world's land has been urbanized, really? A hierarchical framework for avoiding confusion. Landsc. Ecol. 2014, 29, 763-771. [CrossRef]

38. Zhou, D.; Zhang, L.; Hao, L.; Sun, G.; Liu, Y.; Zhu, C. Spatiotemporal trends of urban heat island effect along the urban development intensity gradient in China. Sci. Total Environ. 2016, 544, 617-626. [CrossRef] [PubMed]

39. Zhou, D.; Zhao, S.; Liu, S.; Zhang, L.; Zhu, C. Surface urban heat island in China's 32 major cities: Spatial patterns and drivers. Remote Sens. Environ. 2014, 152, 51-61. [CrossRef]

40. Zipper, S.C.; Schatz, J.; Singh, A.; Kucharik, C.J.; Townsend, P.A.; Loheide, S.P., II. Urban heat island impacts on plant phenology: Intra-urban variability and response to land cover. Environ. Res. Lett. 2016, 11. [CrossRef]

41. Jenerette, G.D.; Harlan, S.L.; Brazel, A.; Jones, N.; Larsen, L.; Stefanov, W.L. Regional relationships between surface temperature, vegetation, and human settlement in a rapidly urbanizing ecosystem. Landsc. Ecol. 2007, 22, 353-365. [CrossRef]

42. Arnfield, A.J. Two decades of urban climate research: A review of turbulence, exchanges of energy and water, and the urban heat island. Int. J. Climatol. 2003, 23, 1-26. [CrossRef]

43. Zhang, Y.; Odeh, I.O.; Han, C. Bi-temporal characterization of land surface temperature in relation to impervious surface area, NDVI and NDBI, using a sub-pixel image analysis. Int. J. Appl. Earth Obs. Geoinf. 2009, 11, 256-264. [CrossRef]

44. Imhoff, M.L.; Zhang, P.; Wolfe, R.E.; Bounoua, L. Remote sensing of the urban heat island effect across biomes in the continental USA. Remote Sens. Environ. 2010, 114, 504-513. [CrossRef]

45. Kuang, W.; Liu, Y.; Dou, Y.; Chi, W.; Chen, G.; Gao, C.; Yang, T.; Liu, J.; Zhang, R. What are hot and what are not in an urban landscape: Quantifying and explaining the land surface temperature pattern in Beijing, China. Landsc. Ecol. 2015, 30, 357-373. [CrossRef]

46. Imhoff, M.L.; Lawrence, W.T.; Elvidge, C.D.; Paul, T.; Levine, E.; Privalsky, M.V. Using nighttime DMSP/OLS images of city lights to estimate the impact of urban land use on soil resources in the United States. Remote Sens. Environ. 1997, 59, 105-117. [CrossRef]

47. Lo, C.; Quattrochi, D.A. Land-use and land-cover change, urban heat island phenomenon, and health implications: A remote sensing approach. Photogramm. Eng. Remote Sens. 2003, 69, 1053-1063. [CrossRef] 
48. Mannino, D.M.; Homa, D.M.; Pertowski, C.A.; Ashizawa, A.; Nixon, L.L.; Johnson, C.A.; Kang, D.S. Surveillance for asthma-United States, 1960-1995. Morb. Mortal. Wkly. Rep. Surveill. Summ. 1998, $47,1-27$.

49. Cutter, S.L.; Finch, C. Temporal and spatial changes in social vulnerability to natural hazards. Proc. Natl. Acad. Sci. USA 2008, 105, 2301-2306. [CrossRef] [PubMed]

50. Claus, R.; Dianne, P.; Kate, B.; Shiraz, N.; Stephanie, G.; Monica, C. The Role of Maps in Neighborhood-level Heat Vulnerability Assessment for the City of Toronto. Am. Cartogr. 2010, 37, 31-44.

51. Patz, J.A.; Campbell-Lendrum, D.; Holloway, T.; Foley, J.A. Impact of regional climate change on human health. Nature 2005, 438, 310-317. [CrossRef] [PubMed]

52. Uejio, C.K.; Wilhelmi, O.V.; Golden, J.S.; Mills, D.M.; Gulino, S.P.; Samenow, J.P. Intra-urban societal vulnerability to extreme heat: The role of heat exposure and the built environment, socioeconomics, and neighborhood stability. Health Place 2011, 17, 498-507. [CrossRef] [PubMed]

53. Johnson, D.P.; Stanforth, A.; Lulla, V.; Luber, G. Developing an applied extreme heat vulnerability index utilizing socioeconomic and environmental data. Appl. Geogr. 2012, 35, 23-31. [CrossRef]

54. Shiklomanov, N.I.; Streletskiy, D.A.; Swales, T.B.; Kokorev, V.A. Climate Change and Stability of Urban Infrastructure in Russian Permafrost Regions: Prognostic Assessment based on GCM Climate Projections. Geogr. Rev. 2017, 107, 125-142. [CrossRef]

55. Li, X.; Li, W.; Middel, A.; Harlan, S.L.; Brazel, A.J.; Turner, B.L., II. Remote sensing of the surface urban heat island and land architecture in Phoenix, Arizona: Combined effects of land composition and configuration and cadastral-demographic-economic factors. Remote Sens. Environ. 2016, 174, 233-243. [CrossRef]

56. Liu, Z.; He, C.; Wu, J. General Spatiotemporal Patterns of Urbanization: An Examination of 16 World Cities. Sustainability 2016, 8, 41. [CrossRef]

(C) 2018 by the authors. Licensee MDPI, Basel, Switzerland. This article is an open access article distributed under the terms and conditions of the Creative Commons Attribution (CC BY) license (http://creativecommons.org/licenses/by/4.0/). 